UDC 620.186. $14: 621.385 .833$

$546.221 .4: 669.14 / .15 .014 .6$

\title{
X 線マイクロ・アナライザーによる
}

\section{鋼中非金属介在物の識別}

Identification of Non-metallic Inclusions in Steel by X-ray Microanalyzer

$\begin{array}{lccccc}\text { 会 } & \text { 員 } & \text { 椙 } & \text { 山 } & \text { 太 } & \text { 郎 } \\ \text { 同 } & \text { 江 } & \text { 口 } & & \text { 勇 } \\ \text { 同 } & & \text { 加 } & \text { 藤 } & \text { 剛 } & \text { 志 } \\ \text { 理 } & \text { 博 } & \text { 渡 } & \text { 辺 } & & \text { 宏* } \\ & & \text { 岡 } & \text { 野 } & & \text { 寛 }\end{array}$

\section{I. 緒 言}

X線マイクロ・アナライザーがCastaingによ り発表されてから約10年となり，金属を始め関 係者の関心も次第に高まってきた。ちょうど， 本年 3 月には Castaing type のカメカ製 Electron Probe Microanalyzer の輸入一号機 が金材技研に入荷した。とれを利用してのデー タる追々発表されることとなろう。しかし，既 に欧米では X線マイクロ・アナライザーを金属 に応用したデータは幾つか報告されている。一 方国内では国産機の研究が各メーカーにより鋭 意進められており，ここ一，二年の間に飛矅的 な進歩を遂げ，既に奏用の段階まで到達したと 考元られる。

われわれは本機に対する日立製作所の試作研 究と暁行して，その実用試験に関して種々の試 料で倹討を行ってきた。そこで充分とはいえな いが、いままでに得られた結果の一端を発表す る. 主として日立製試作 3 号機により，冶金学 上最子複雑，かつ興味ある対象たる䣄中非金属 介在物についての実験結果について述べる。

從来，敛中非金属介在物の識別分類について は顕微鏡試験, $\mathrm{X}$ 線回折, あるいは化学分析等
種々の手段を利用して多数の研究が行われてい るが，その何れもが，間接的判断またはいくつ かの介在物の平均値の測定が殆んどであった。 すなわち従来用いられてきた方法では個々の介 在物についての解釈が必ずしも正確にして充分 であるとはいえなかった，X線マイクロ・アナ ライザーは微視的, 局所的な試料成分の二次元 的な分布を直接知り得るという，画期的な特徽 を有しているのでわれわれはての点を利用して 直接鋼中に存在する個々の介在物の成分々布を 調查し, 非金属介在物の正確な識別を行うこと を試みた。

\section{II. 実 匼 装 置}

実験に用いたX線マイクロ・アナライザーは 日立製作所の研究になる試作 3 号機 (XMA-3 型)である、装置の詳細は筆者のうちの一人 により，別に報告されているのでことでは省略 小.

なお本機には絶えず改良か加えられているが 最近更に一段と改善が行われ，近くまとまった 姿で世に出ることになっている。

III. 実験および実験結果 2 )

* 日立製作所 中央研究所

（1）渡辺：計測， 11 (1961) 1, 渡辺：金属誌，23 (1959) A255

（2）実験結果の横朝は武料上の距離的位置関係を示し，縦軸は各元素の特性 X 綜の count 数に対応 する. 
（1）鉛一硫黄系快削鋼中の介在物について 鉛一硫黄系快削鋼で介在物（非金属，金属を 含め）といえば硫化物および鉛が挙げられる。 前者は試料の研磨状態でその形状は簡単に観察 できる.しかしその組成に関しては窗蝕試験あ るいは抽出分離して化学分析，X線回折等によ るのが普通であるが，简蝕武験の結果はあいま いで間接的である，抽出分離による方法は操作が複雑で, かつ平均的数值である，Pb 亿つい ては発汗試験，KI 简蝕試験あるいは microradiography 等が用いられているが，何れも 間接的であり，操作す複雑である。

このような介在物にX線マイクロ・フナライ ザーを用いることにより試料は非破壊の状態 で，かつ介在物および基地とを関連させて micro 的な各元素の濃度分布を知ることができ る.

硫化物と考えられる第1図に示すような介在 物（灰黒色部分全体が硫化物であり，その端に あるいは離れて基地中に点在する黒点が $\mathrm{Pb}$ と 思われる)についててれを直角に横切るように 基地と介在物の $\mathrm{Fe}, \mathrm{Mn}, \mathrm{S}$ および $\mathrm{Pb}$ の濃

第 1 困 鉛一硫黄系快削鋼中の介在物

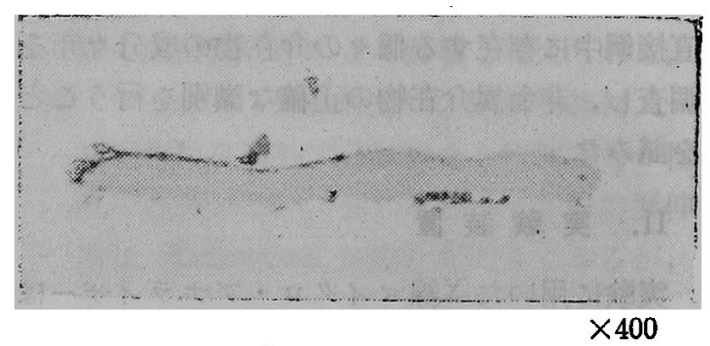

○試料の化学成分 (\%)

\begin{tabular}{|c|c|c|c|c|c|c|c|}
\hline $\mathrm{C}$ & $\mathrm{Si}$ & $\mathrm{Mn}$ & $\mathrm{P}$ & $\mathrm{S}$ & $\mathrm{Cu}$ & $\mathrm{Pb}$ & $\mathrm{Al}$ \\
\hline 0.09 & 0.02 & 1.07 & 0.056 & 0.44 & 0.03 & 0.20 & 0.004 \\
\hline
\end{tabular}

○ Klinger Koch 法による抽出物のX線回折結果 : $\alpha \mathrm{MnS}$

度分布を調べた結果を第2，3図に示す，てれに よるとこの介在物はやはり硫化物であり，また 個々の硫化物の組成はバラッキが多く一様でな いことがわかる，すなわち硫化物によって Fe, $\mathrm{Mn}$ の濃度が異る。しかし Fe の濃度は0でな いので各硫化物は Fe-Mn-S 系のものである
第 2 図 Fe および Mn の濃度分布

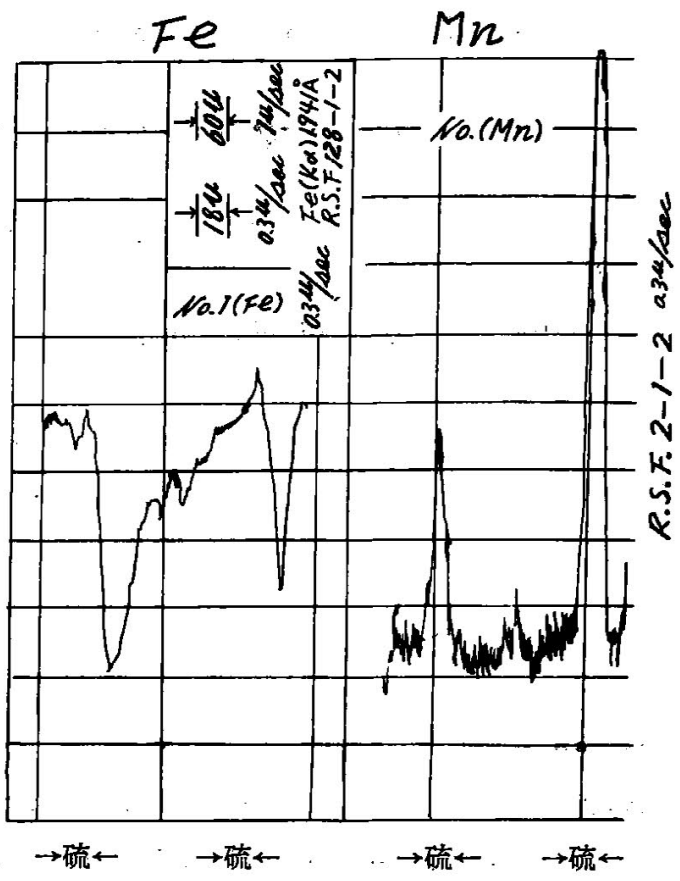

第 3 図 $\mathrm{S}$ および $\mathrm{Pb}$ の濃度分布

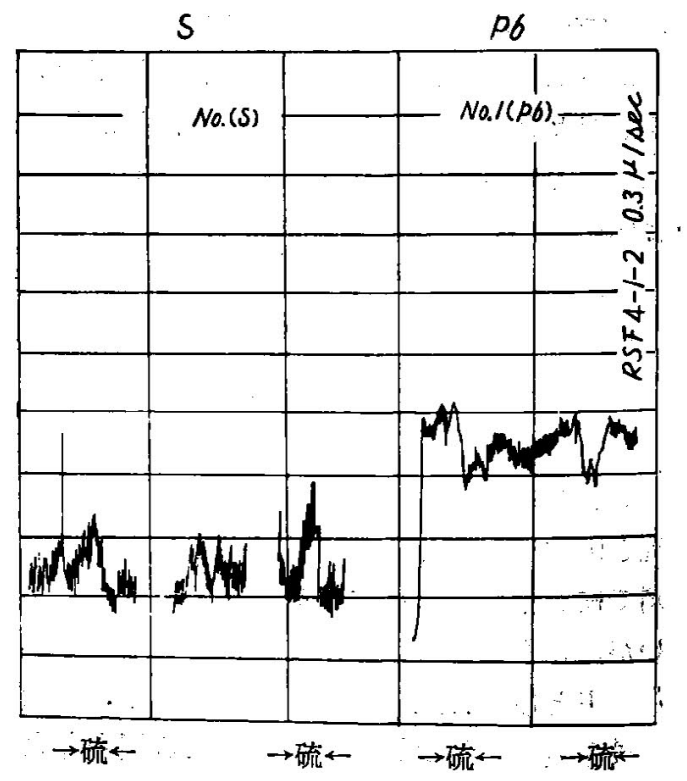

と考えられる：Klinger Koch 式電解分離装置 で抽出した介在物の X 線 回折の結果からは $\boldsymbol{\alpha}$-MnS の結晶構造が得られているので各研化 物は量的なバラッキはあるが、FeS を固溶じた $\alpha-\mathrm{MnS}$ であるといえる.

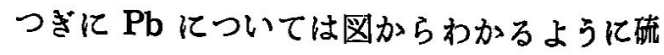


化物中には存在せず，硫化物の端あるいは離れ て単独に存在するてとが認められた。なお $\mathrm{Pb}$ は硫化物のとてろで必ず低い濃度を示してい る. 基地ではてれより全般に高い濃度である。 かつ，ところどてろにピークがみられる..てれ が恐らく $\mathrm{Pb}$ 粒と思われる。またての部分では Sのピークがみられないから PbS のような化 合物は構成していないといえる，硫化物の部分 の $\mathrm{Pb}$ の浱度を 0 と考えると基地の $\mathrm{Pb}$ 湌度が それより高いというととは $\mathrm{Pb}$ がある程度基地 に固溶していることを示すのではないかとも思 われる。

(2) 珪酸質介在物について

1）不透明二相介在物

平均組成 $\mathrm{SiO}_{2}$ を数十\%含む理酸質介在物の うち，第4図に示すような黒色および灰黒部分 の二相からなる不透明介在物の各部分の $\mathrm{Fe} お$ よびMn の濃度分布を調査した結果は第5，6図 の通りで, 黒色部分の $\mathrm{Fe}$ 濃度は殆んど 0 に近

第 4 図 二相汃らなる不透明介在物（I）

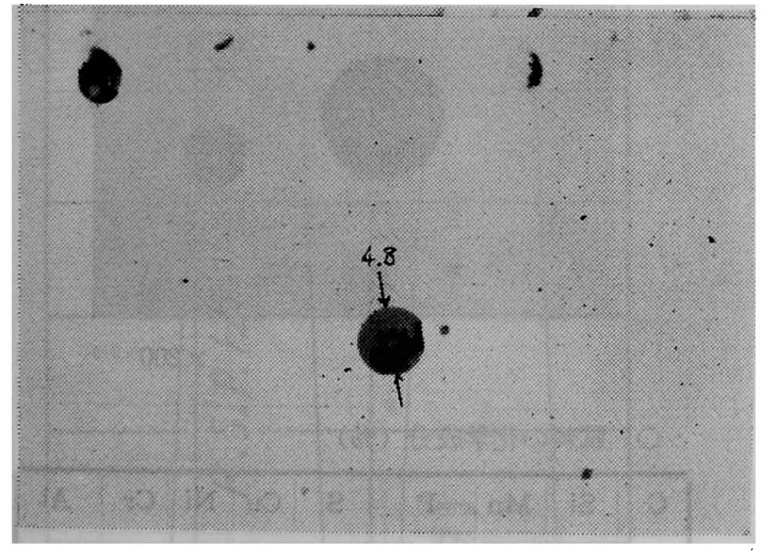

A

$\times 200 \times 2 / 3$

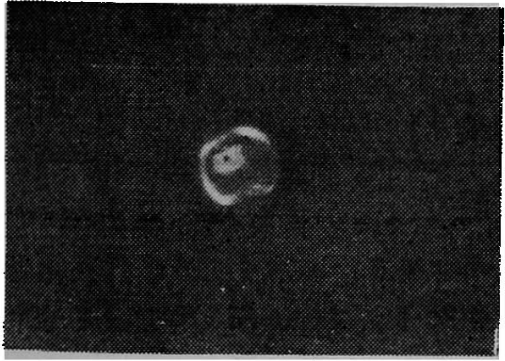

B

(徧光) $\times 200 \times 2 \cdot 3$

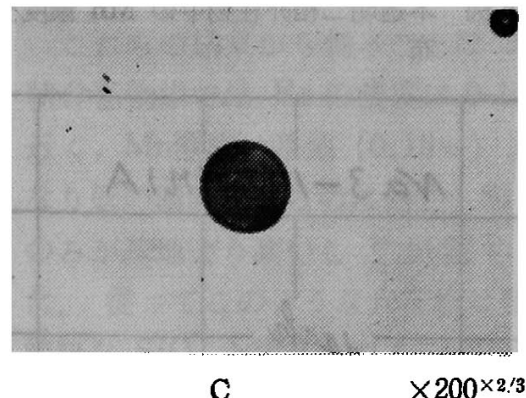

○試料の化学成分 (\%)

\begin{tabular}{|c|c|c|c|c|c|c|c|}
\hline C & $\mathrm{Si} \mathrm{Mn}$ & $P$ & $S$ & $\mathrm{Cu}$ & $\mathrm{Ni}$ & $\mathrm{Cr}$ & $\mathrm{Al}$ \\
\hline & 330. & 0.018 & & & & 0.10 & \\
\hline
\end{tabular}

○介在物の平均組成 (\%)（湿硝酸法分析値）

\begin{tabular}{|c|c|c|c|}
\hline $\mathrm{SiO}_{2}$ & $\mathrm{MrO}$ & $\mathrm{F} \in \mathrm{O}$ & $\mathrm{Al}_{2} \mathrm{O}_{3}$ \\
\hline 67.6 & 16.7 & 12.2 & 3.5 \\
\hline
\end{tabular}

第 5 図 不透明二相介在物中の $\mathrm{Fe}$ 濃度分布 Fe

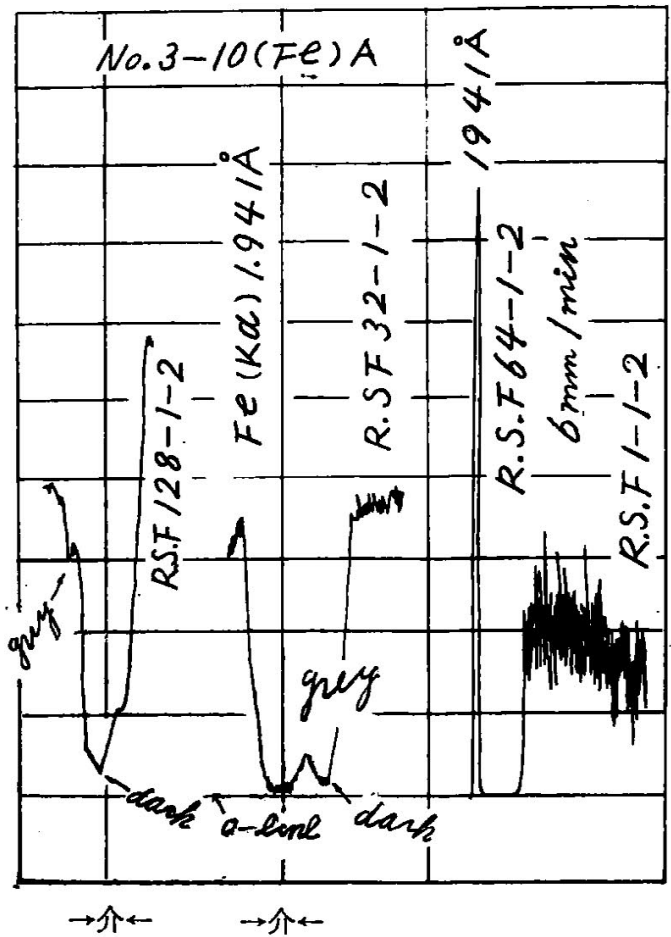

く, 逆に Mn の濃度が著しく高い. 恐らくMn 一silicate と考元られる. 一方, 灰黒色部分に は Fe およ゙ば Mn の雨元素の存在が認められ， 
第 6 図 不透明二相介在物中の $\mathrm{Mn}$ 濃度分 布

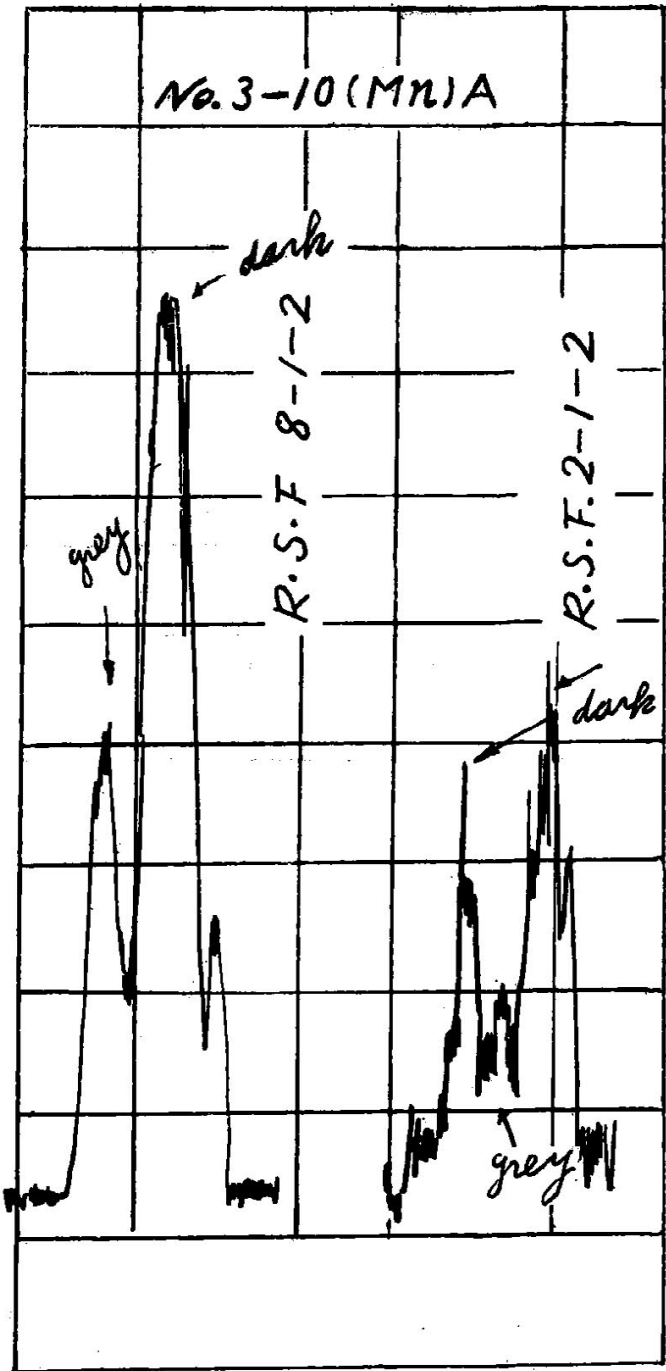

$\rightarrow$ 介

$\rightarrow$ 介

この部分は $\mathrm{Fe}-\mathrm{Mn}$-silicates と判断される. このように色の異るそれぞれの相は别の組成か らできているととがわかった。

ロ）透明ガラス状介在物

第 7 図に示す珪酸質介在物の試料では上述の 不透明二相介在物も一部存在するが，大部分は 下の写真（特に偏光ではっきりクロスが見られ る介在物）汇認められるようながラス状で同心 円をなす透明な介在物である。この試料の介在 物の平均組成は第 7 図に示すように殆んど
第 7 图 ガラス状透明介在物
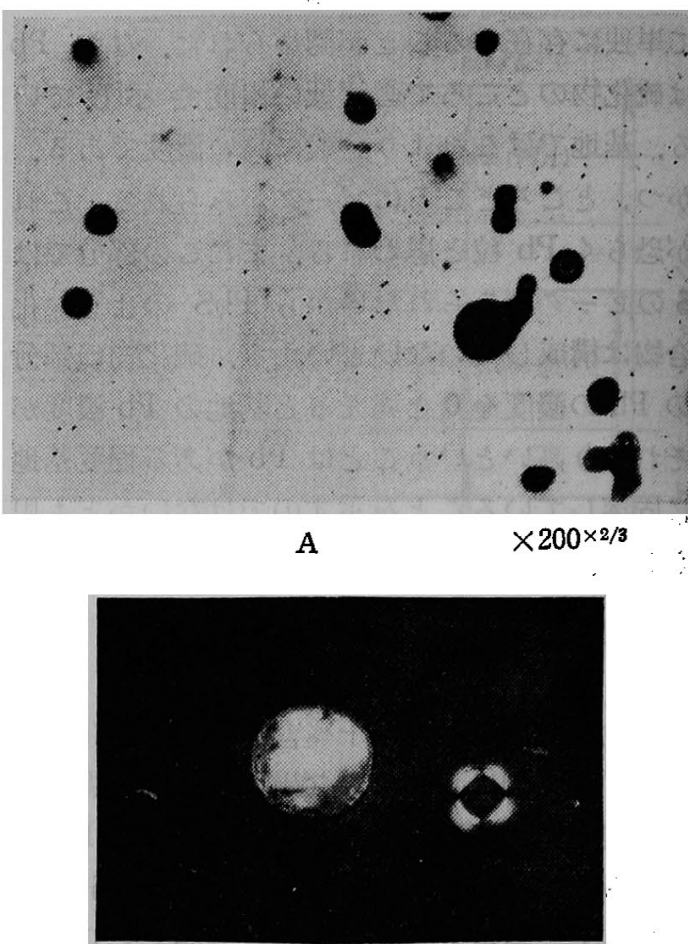

B (偏光) $\times 500 \times 2 / 3$

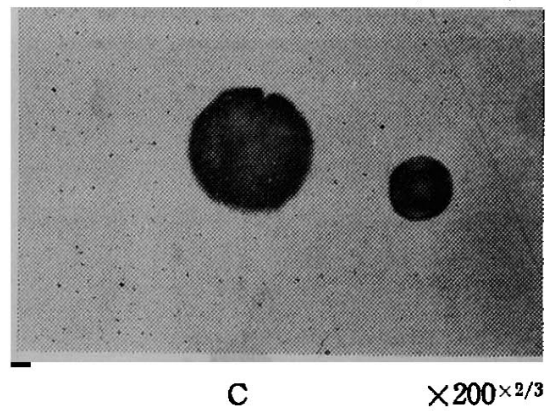

○試料の化学成分 (\%)

\begin{tabular}{|c|c|c|c|c|c|c|c|c|}
\hline $\mathrm{C}$ & $\mathrm{Si}$ & $\mathrm{Mn}$ & $\mathrm{P}$ & $\mathrm{S}$ & $\mathrm{Cu}$ & $\mathrm{Ni}$ & $\mathrm{Cr}$ & $\mathrm{Al}$ \\
\hline 0.09 & 0.05 & 0.15 & 0.018 & 0.013 & 0.21 & 0.08 & 0.09 & 0.002 \\
\hline
\end{tabular}

○ 介在物の平均組成（\%）（温硝酸法分析値）

\begin{tabular}{|c|c|c|c|}
\hline $\mathrm{SiO}_{2}$ & $\mathrm{MnO}$ & $\mathrm{FeO}$ & $\mathrm{Al}_{2} \mathrm{O}_{3}$ \\
\hline 95.1 & 2.7 & 1.1 & 1.1 \\
\hline
\end{tabular}

$\mathrm{SiO}_{2}$ からなるものである。ガラス状透明介在 物について第 8 図に示すように介在物を横ぎ て直線状に $\mathrm{Fe}, \mathrm{Mn}, \mathrm{Si}$ 等の濃度分布を調べ た結果を第 9 〜11図に示す。 
第 8 図電子線照射による contamination と カラス状介在物

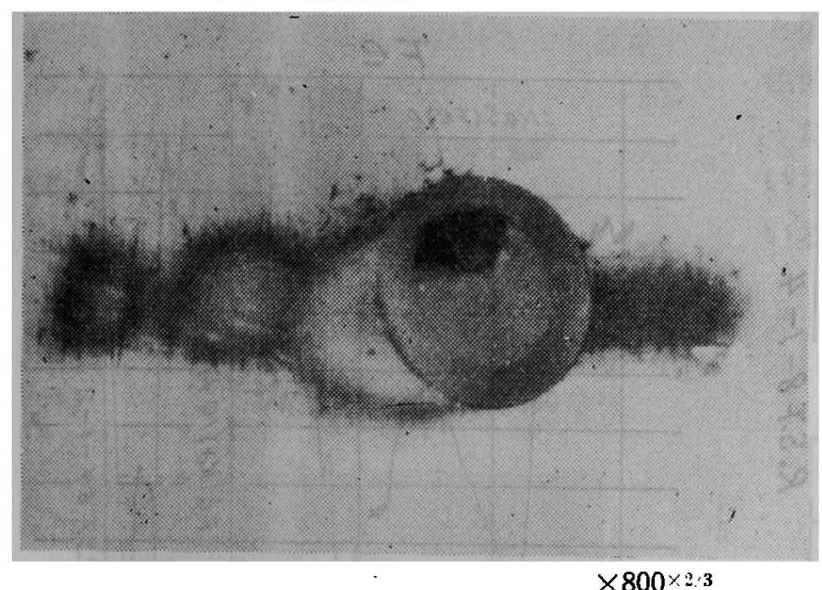

$\times 800 \times 2.3$

第 9 四 ガラス状透明介在物中の Fe 濃度分布

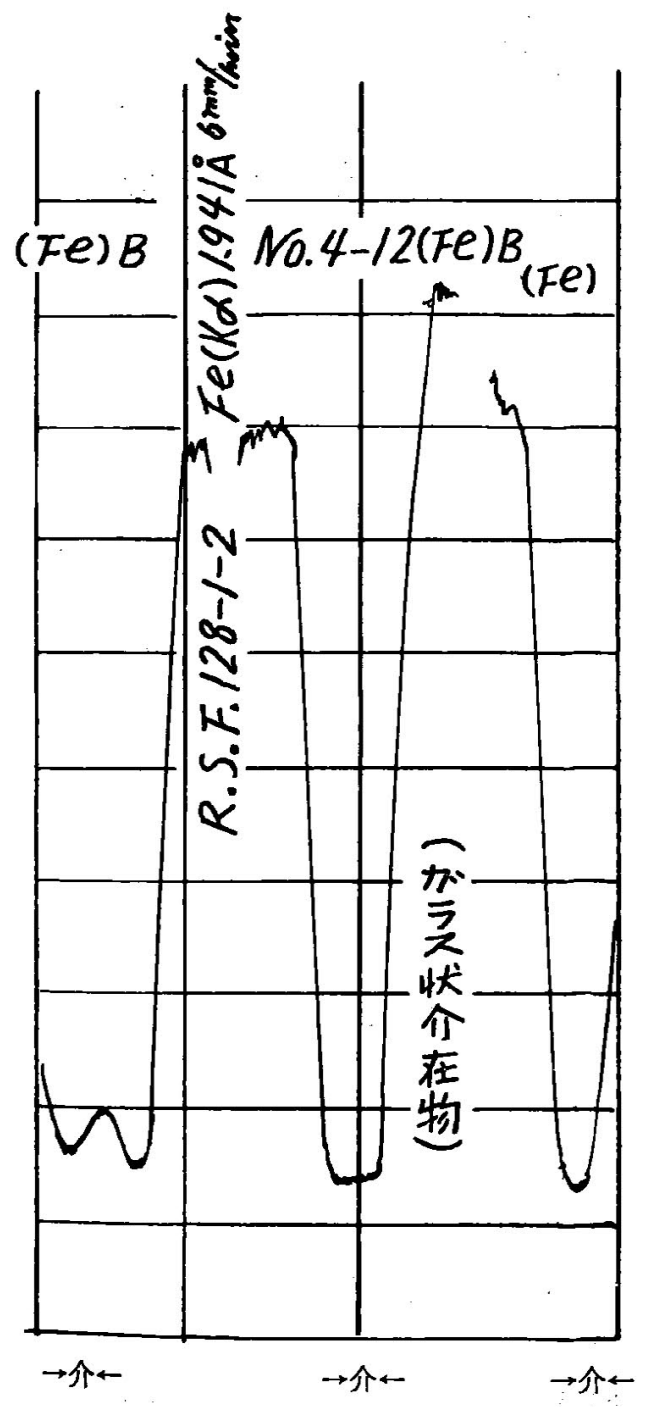

これらの結果から判ることはガラス 状介在物中では $\mathrm{Fe}$ の濃度は 0-line に 近く, Mn濃度は基地（0.15\%）よりか なり低い濃度であるのに対し, $\mathrm{Si}$ 濃度 のみが基地より高いことが認められ た。 従っててのような介在物は殆んど 純精な $\mathrm{SiO}_{2}$ と考えられる。

八）不透明二相介在物

第12図に示すような介在物の平均組 成 $\mathrm{SiO}_{2} 52.5 \%, \mathrm{FeO} 47.5 \%, \mathrm{Al}_{2} \mathrm{O}_{3}$, $\mathrm{MnO}$ tr. である $\mathrm{FeO}-\mathrm{SiO}_{2}$ 系の二相 介在物について $\mathrm{Fe}, \mathrm{Si}, \mathrm{Al}$ 等の濃度

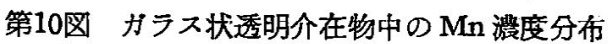

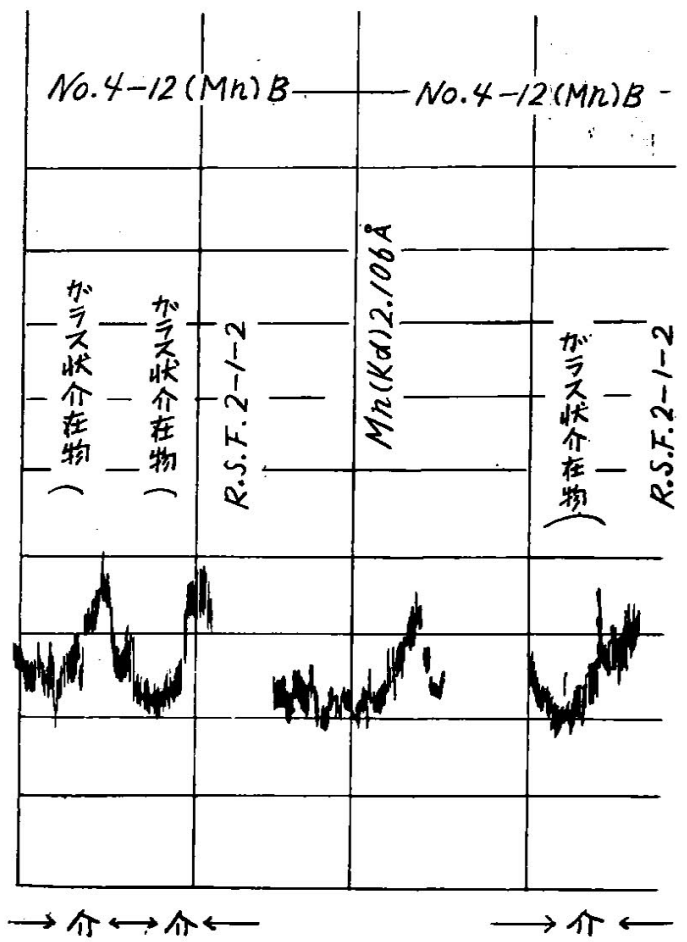

分布を調査した結果を第13，14図に示す，乙れ より黒色部分は $\mathrm{Fe}$ 濃度が非常に低く $\mathrm{Si}$ 濃度 が高い。

從って純 $\mathrm{SiO}_{2}$ に近いと考えられる。一方，灰 黒色部分は $\mathrm{Si}$ 濃度が低く, Fe 濃度が高い従? て純 $\mathrm{FeO}$ 亿近いと考元られる。 $\mathrm{FeO}$ 油抽出物 の X線回折の結果確かめられている，なお $\mathrm{A} 1$ の介在物中における濃度分布については第14図 
第11図 ガラス状透明介在物中の Si 濃度分布

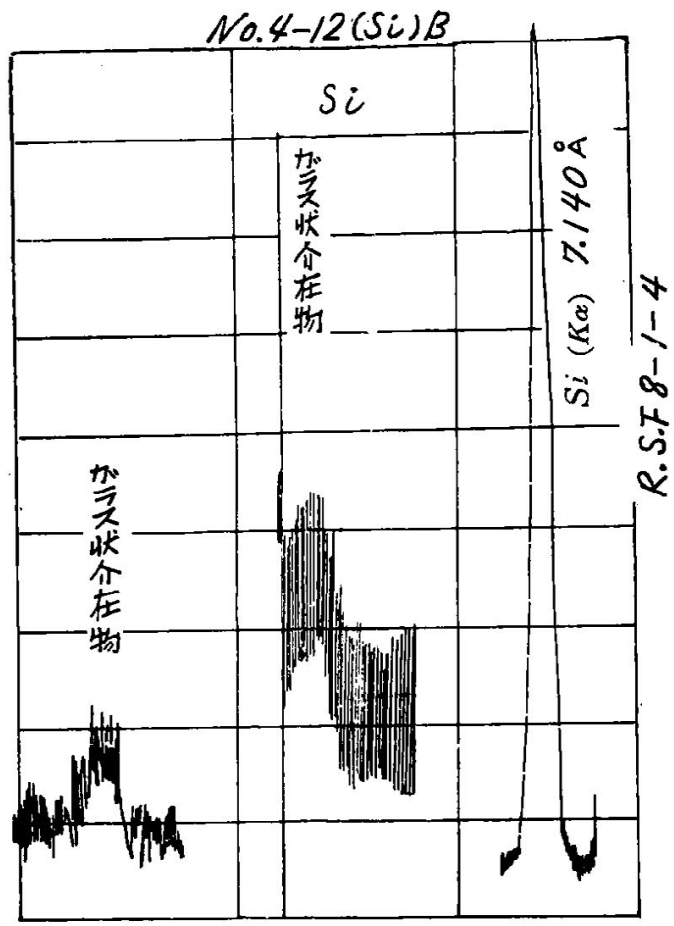

$\rightarrow$ 介心

第12四 不透明二相介在物 (II)

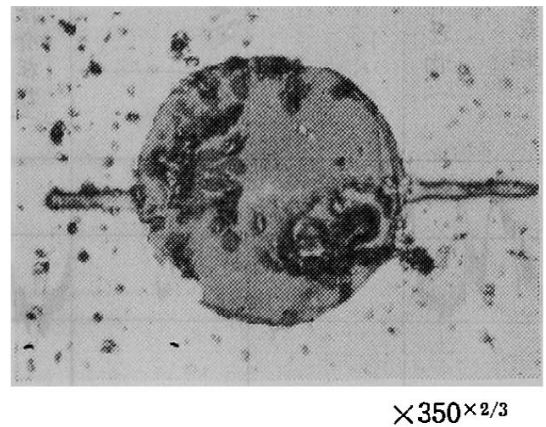

○試料の化学成分 $(\%)$

\begin{tabular}{|c|c|c|c|}
\hline $\mathrm{C}$ & $\mathrm{Si}$ & $\mathrm{Mn}$ & $\mathrm{Al}$ \\
\hline 0.007 & 0.67 & tr. & 0.003 \\
\hline
\end{tabular}

○ 介在物の平均組成（\%) (Klinger Koch 法による介在物分析值)

\begin{tabular}{|c|c|c|c|}
\hline $\mathrm{SiO}_{2}$ & $\mathrm{FeO}$ & $\mathrm{Al}_{2} \mathrm{O}_{3}$ & $\mathrm{MnO}$ \\
\hline 52.5 & 47.5 & tr. & tr. \\
\hline
\end{tabular}

○ Klinger Koch 法による抽出物のX線回折 結果 : $\mathrm{FeO}$
第13図 不透明二相介在物 (II) 中の $\mathrm{Fe}$ 䟴度分布

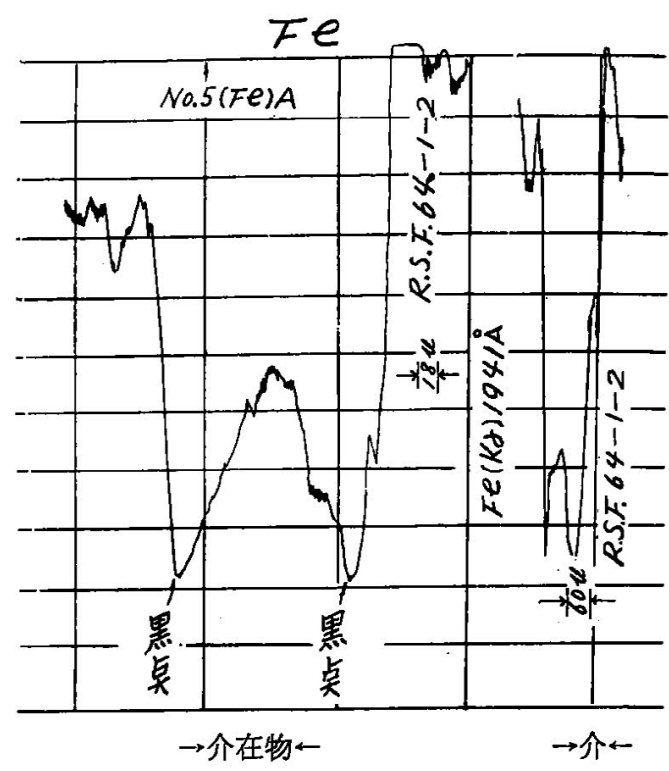

第14図 不透明二相介在物 (II) 中の Si および Al 濃度分布

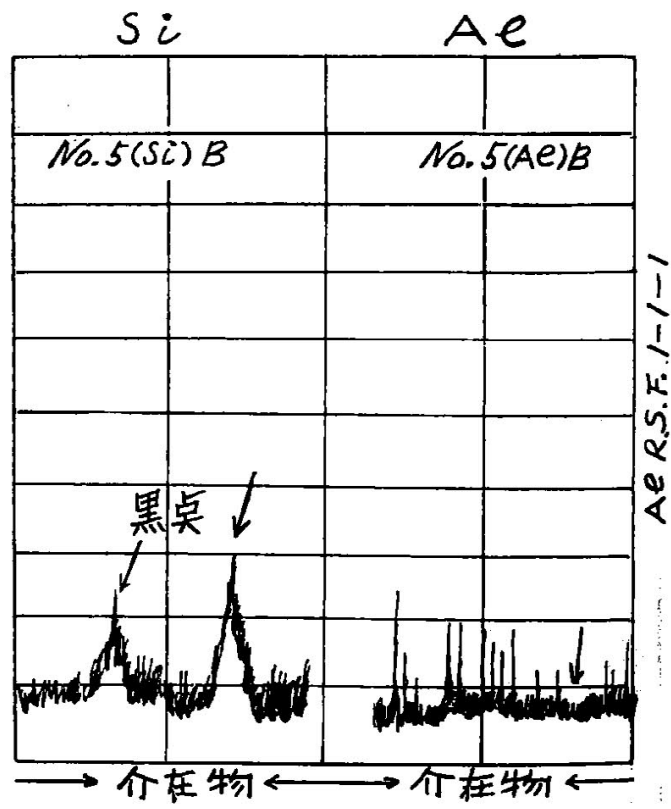

にみられるように基地と殆んど差はなく，また 黒色あるいは灰黒色の相とは特別に関係はない ようである。

）高温水素処理した不透明珪酸質介 在物

第15図に示す平均組成を有する不透明珪酸質 
第15四 不透明珠酸質介在物の高温水素処理

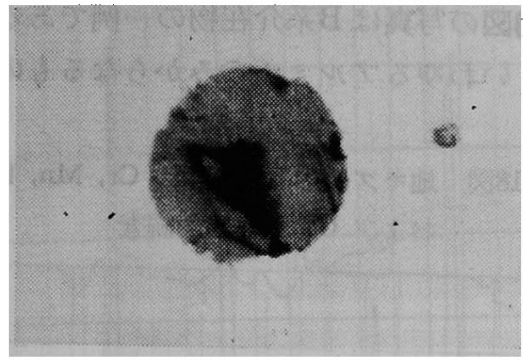

A 処理前 $\times 540 \times 2 / 5$

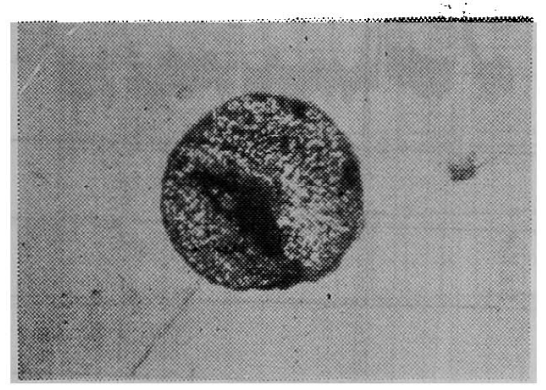

B $\quad 1000^{\circ} \mathrm{c} \times 2 \mathrm{hrH}_{2}$ 処理 $\times 540 \times 2 / 3$

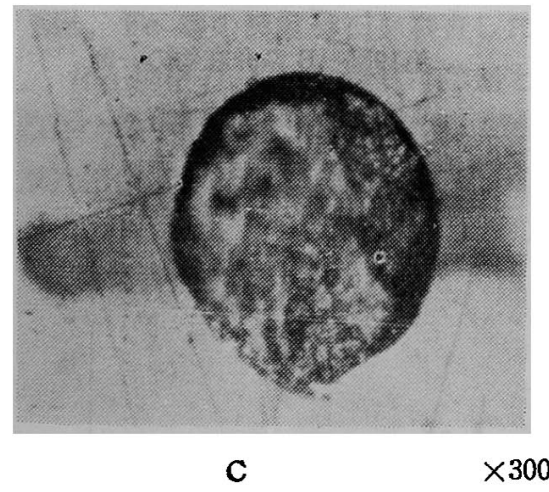

○ 分析した介在物の一例 (contamination か; ついている)

○ 試料の化学成分 $(\%)$

\begin{tabular}{|c|c|c|c|c|}
\hline $\mathrm{C}$ & $\mathrm{Si}$ & $\mathrm{Mn}$ & $\mathrm{S} . \mathrm{Al}$ & $\mathrm{I} . \mathrm{Al}$ \\
\hline 0.005 & 0.67 & tr. & $<0.002$ & $<0.002$ \\
\hline
\end{tabular}

○ 介在物の平均組成 $(\%)$ (Klinger Koch 法による介在物分析值)

\begin{tabular}{|c|c|c|c|}
\hline $\mathrm{SiO}_{2}$ & $\mathrm{FeO}$ & \multicolumn{1}{c|}{$\mathrm{At}_{2} \mathrm{O}_{3}$} & $\mathrm{MnO}$ \\
\hline 73.7 & 16.9 & 9.4 & tr. \\
\hline
\end{tabular}

介在物を水素気流中 $1000^{\circ} \mathrm{C}$ で $2 \mathrm{hr}$. 処 理 する と第15図の写真にみられるように介在物の灰黒 色部分が還元されて基地鉄と同じ金属光沢をも った白点が多数生成する．ての白点が密集して いる部分の Fe 浱度は第16図の結果に示されて いる如く，基地鉄の $\mathrm{Fe}$ 濃度に近くなってい

第16図 高温水素処理した不透明珄酸澌介在 物中の Si および Fe の濃度分布

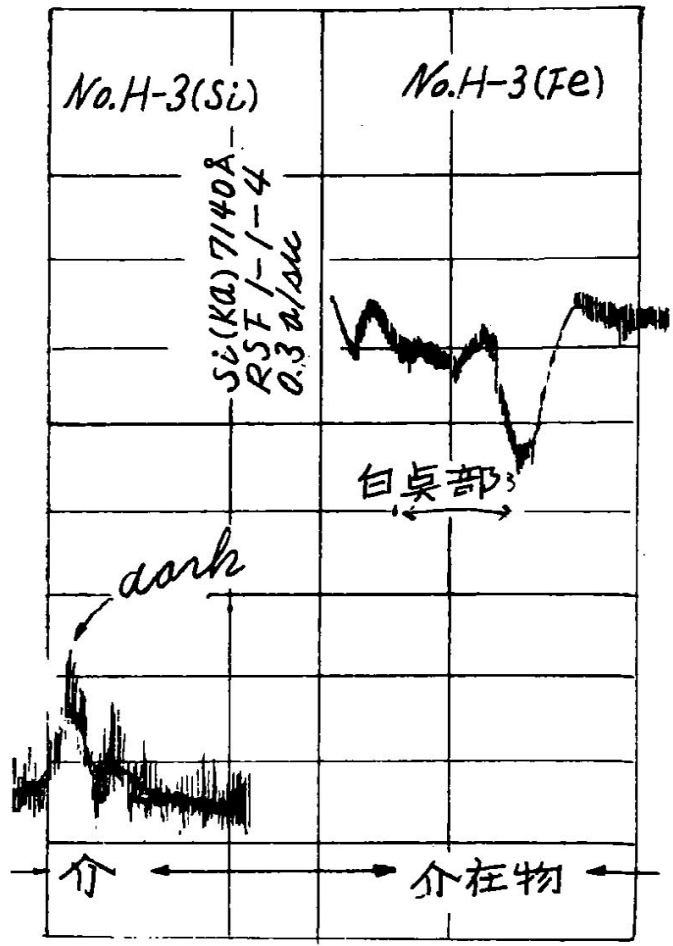

ろ. 一方, 水素による還元作用によっても変化 しなかった黒色部分（第15罒の下の写真）の Fe 濃度は基地鉄部分よりはるか亿低い，しか しかなりの含有量である。しかもこの部分の $\mathrm{Si}$ 濃度は高い，従って確かに処理前の介在物の 灭黒色部分は Fe の oxide を主成分とするも のであつて, 高温水素処理によって金属鉄に還 元されたものと考えられる。また，黒色部分は Silicate とみなされる。

（3）地キズのA系介在物の一例

第17図に示すようなステンレス（SUS22）鋼 
第17怄 ステンレスの地キズのA系介在物
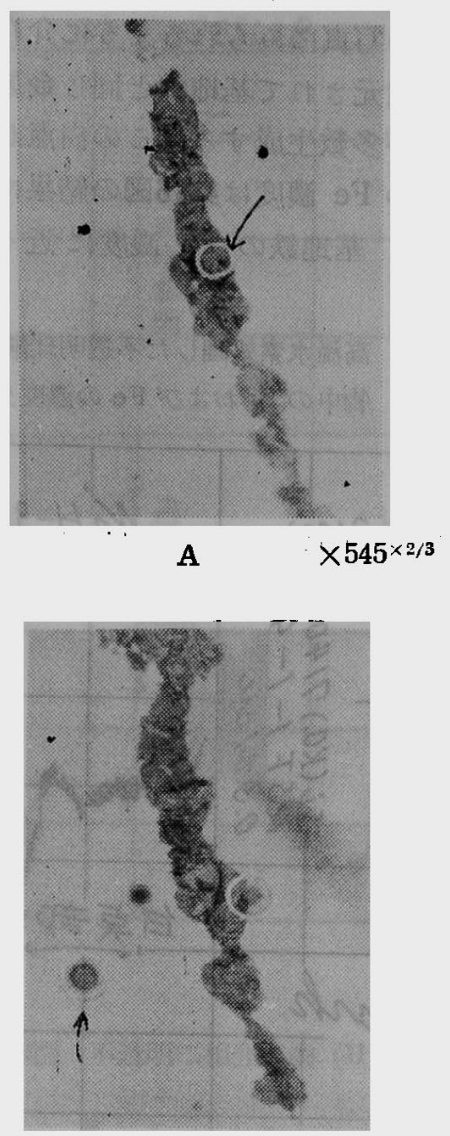

B

$\times 545^{\times 2 / 3}$

○試料の化学成分 (\%)

\begin{tabular}{|c|c|c|c|c|c|c|c|c|}
\hline 鋼 種 & $\mathrm{C}$ & $\mathrm{Si}$ & $\mathrm{Mn}$ & $\mathrm{P}$ & $\mathrm{S}$ & $\mathrm{Cu}$ & $\mathrm{Ni}$ & $\mathrm{Cr}$ \\
\hline SUS22 & 0.16 & 0.41 & 0.67 & 0.018 & 0.008 & 0.14 & 0.11 & 12.94 \\
\hline
\end{tabular}

の段削聇見試験材に地キズとして存在するA系 介在物について $\mathrm{Cr}, \mathrm{Fe}, \mathrm{Mn}, \mathrm{Ca}$ 等の元素か 存在するかどうかる定性的3) 亿調査した，各元 素の検出に利用した特性X線は $\mathrm{CrK} \alpha, \mathrm{FeK} \alpha$, $\mathrm{MnK} \beta$ わよび $\mathrm{CaK} \alpha$ である。得られた結果を 第18図に示す，その結果 $\mathrm{A}$ 系介在物中に $\mathrm{Cr}$, $\mathrm{Fe}, \mathrm{Mn}$ および Ca の何れもが存在するてと並 びに Ca は基地にはなく地キズの介在物中のみ に存在することを認めた。
（4） B 系介在物の一例

第19図の写真は B系介在物の一例である，た だし，いわゆるアルミナのみからなるものでは

第18図地キズのA系仝在物の $\mathrm{Cr}, \mathrm{Mn}, \mathrm{Fe}$, および Ca の定性的調查

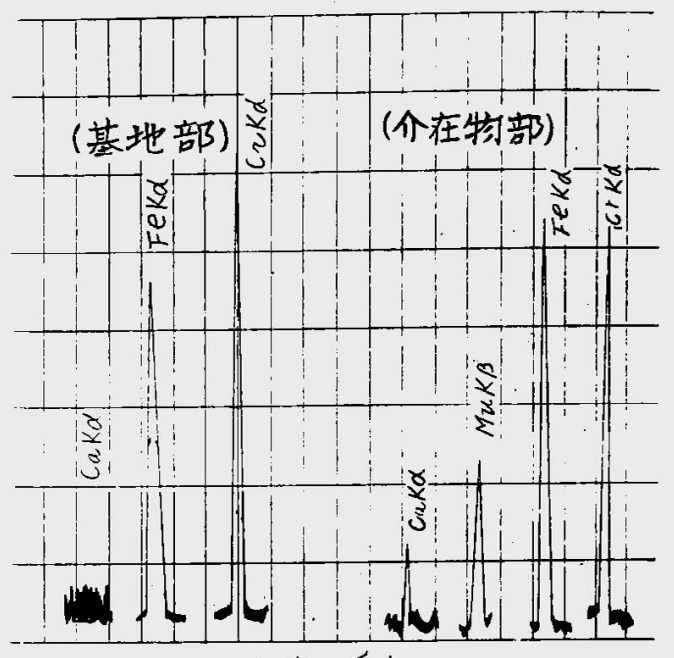

(波長)

第19図 B 系介在物の一例

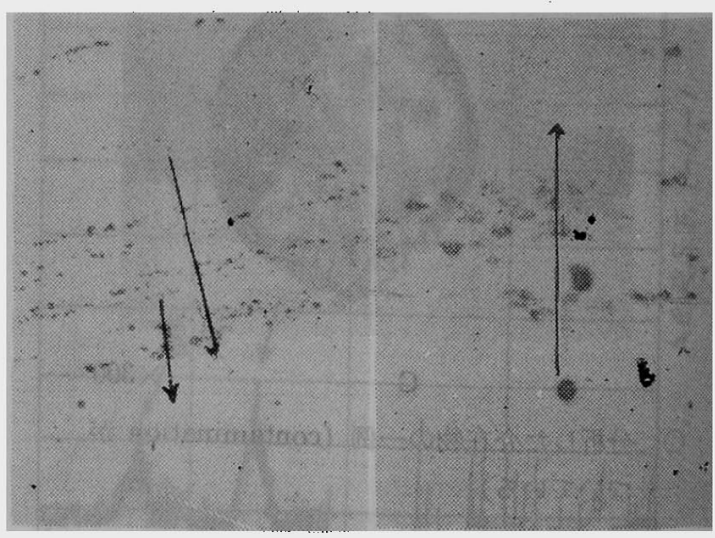

A $\quad \times 140 \times 23$

B $\times 540 \times 2 / 3$

試䊀の化学成分 (\%)

\begin{tabular}{|c|c|c|c|c|c|c|c|c|}
\hline 鋼 種 & C & Si & Mn & P & S & Cu & Ni & Cr \\
\hline S15CK & 0.17 & 0.220 .50 & 0.009 & 0.013 & 0.18 & 0.07 & 0.08 \\
\hline
\end{tabular}

3）エレクトロンビームを試粸上の一点に当て波長分析を行う. 従って実験結果の横軸は特生 X線の波 長に対応し，縦軸は X 線強度に対庶する. 
第20四 B系介在物およびその近停の Mnの擞度分布

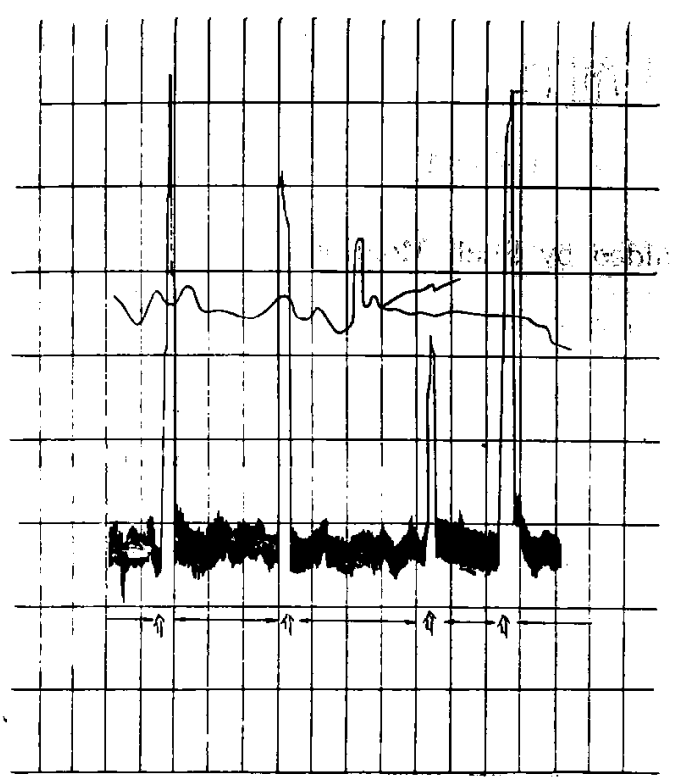

なく，電子回折の結果， $\mathrm{MnO}$ その他の種々の 酸化物の小粒介在物から構成される $\mathrm{B}$ 系介在物 がある.との介在物の列を直角に横切るように $\mathrm{Ca}, \mathrm{Mn}, \mathrm{Fe}$ 等の濃度分布を調査した。 その 結果, 介在物帯の $\mathrm{Ca}$ の濃度は基地と変りな く，Caの存在は認められなかった，Mnについ ては第20図に示すように介在物の部分に大きな 檂度変化がみられ，介在物中にかなりの Mnが
存在するととが認められた。またこの部分では $\mathrm{Fe}$ 濃度が減少していた。

なお第20図においてモニターと記してあるの は入射ビーム強度の変化, 試料表面の凸等に 対応する curve である（これについては別に 詳しく報告される）が, 介在物のとてろにおけ 万特性 X線の強度変化とは対応していない，従 つて上述の結果は純粋な元素の濃度変化と考元 てよい。また前節までの測定に用いたような試 料のバフ精研磨状態（no-etch）ではモニダー による大きな変化が現われる程の試料表面の凹 凸はないことを一応確かわた。

\section{IV. 結 言}

$\mathrm{X}$ 線 microanalyzer の用として錀中非金 属介在物の識別に関する結果について報告し た、このような装置の利用により，従来われわ れか種々の手段, 主として間接的な方法によっ て判断してきた非金属介在物の実体が直接的な 方法により奏証できたり，また従来の荐え方に 疑問が持たれる等興味ある結果が得られた，特 に従来の判定結果に対する疑問は Castaing ら の実験結果にもいくつか示されており, 非金属 介在物の研究のみでなく，広く金属の組織一般 の解秎に新しい進歩をもたらすものと期待され る. 